\title{
Comparison of Politeness and Acceptability Perceptions of Request Strategies between Chinese Learners of English and Native English Speakers
}

\author{
Yu-Cheng Lee \\ Fudan University, Shanghai, China \\ E-mail: ycl1978@hotmail.com
}

Received: February 26, $2011 \quad$ Accepted: March 28, $2011 \quad$ doi:10.5539/ass.v7n8p21

\begin{abstract}
The politeness issue has received much attention in China in recent years. In regard to Chinese learners of English however, there is still a large gap between politeness displayed and what is felt in western cultures as politeness appropriate. This leads to the unfortunate labeling of Chinese learners of English as "impolite". While the author does not feel this is necessarily so, the fact remains that language production by Chinese learners and the language expectations by native English speakers show great gaps. This article attempts to identify the factors which affect Chinese English learners' perceptions of degree of politeness needed in differing situations, and also to study these learners' perceptions of how much politeness is shown by differing request strategies. After comparing these results with native English speakers, discrepancies between the two groups are analyzed, and an explanation is ventured.
\end{abstract}

Keywords: Politeness, Cultural differences, Cognitive linguistics, Request strategies, Power and imposition

\section{Introduction}

There has been increasing sentiment in the past twenty to thirty years among various scholars that different cultures differ too much in their ideals of politeness to warrant studies of the cross-cultural kind. Therefore, the author aims to determine, from a cognitive linguistic point of view, if Chinese learners of English and native speakers differ overly much in their frames of what politeness is, how politeness is displayed, and degree of politeness needed in differing situations. The purpose of this study is to discern how the factors of power and imposition (as described by Brown and Levinson) affect Chinese learners' feelings about acceptability of request strategies, and to see if there is divergence with western native speakers' judgments.

\section{Literature review}

\subsection{Cultural variability and factors affecting degree of politeness}

While the author hypothesizes that Chinese learners of English and western native speakers share very common views on what politeness is, it is still interesting to note that the two groups choose to utilize differing strategies in interaction, leading to the unfortunate distinction of some Chinese learners as "impolite". According to Holtgraves and Yang (1990), cultural variability in politeness strategies can be accounted for "in terms of cultural differences in the values that are assigned to distance, power, and imposition variables" (pg. 720). The author's earlier work has shown that the factors of power and imposition have similar effects on both Chinese learners of English and western native speakers, the two factors which will be further analyzed in this current paper. The effect of power and imposition variables have also been supported by earlier studies such as Blum-Kulka et al. (1985), Holtgraves and Yang (1990, 1992), Leichty and Applegate (1991), Brown and Gilman (1989), and Leichty and Applegate (1991) respectively. More problematic has been the distance factor. This factor has brought about divergent findings not only among Chinese learners of English from the author's previous study, but also among native English speakers themselves, as has been shown from the studies of Davis (1982), Baxter (1984), Mclaughlin et al. (1983), Slugoski and Turnbull (1988), Holmes (1990), and Holtgraves and Yang (1990). For this reason, the current study adopts the attitude that this factor should be put aside until further research better defines the parameters of just what distance is. As many researchers have identified before, the issue at the heart of the problem involves separating the effects of "attraction" and actual "social distance". Up to date, the author is not aware of any research that has managed to do this. 


\subsection{A cognitive view of politeness}

If we look at the politeness phenomenon from the point of view taken by Watts (2005), we might hazard a guess that what is deemed appropriate in talk differs between these two groups (Chinese learners of and native speakers of English). An alternative to both Brown and Levinson and the relativity hypothesis to politeness which still addresses the issue of cultural specificity while incorporating aspects of the relational theory lies within seeing the politeness phenomenon from a cognitive point of view. The concept of frame as an organized set of specific knowledge can be very helpful towards explaining politeness as neither inherently universal, nor totally culture-specific. Minsky $(1975,1986)$ explains frame as a data structure for representing a stereotyped situation. Schank and Abelson (1977) state that script (their label for the frame concept) is "a structure that describes appropriate sequences of events in particular contexts. A script is made of slots and requirements about what can fill those slots." Politeness therefore could be seen as a set of expectations about socially acceptable behavior under differing circumstances.

If we look at children, it is easy to see that politeness does not come naturally. Rather, it is a skill and set of knowledge which must be constantly reinforced through instruction from parents and teachers and also practiced through daily interaction with others. It is through this frequent reiteration of what is acceptable or non-acceptable that we learn to display "proper" behavior and language. In short, we form our frames about politeness according to the environment and culture in which we live.

The cognitive approach can help to explain why there are difficulties in performing cross cultural politeness research. Escandell-Vidal (1996) explains very simply "specific knowledge" (in this case of politeness) "is specific because there are different situations with different actions, participants and properties, but also because there are different cultures." She also adds "culturally determined (sub)sets of assumptions govern the interaction in a permanent and automatic way" (pg. 629). Any behavior or utterance which deviates from the frame of a particular culture will of course be seen as strange or impolite/inappropriate in that particular culture.

The question that we as linguists must ask when performing cross cultural studies of politeness is not only simply "what is politeness?" but also "what is politeness for each of the speech communities under study, and do their cognitive frames of politeness converge enough to warrant comparison?"

If we think of social interactions as frames in the cognitive domain of individuals, there is less need to analyze politeness in very strict and rigid terms of face and facework. More simply, we could proceed with the study of politeness as different expectations of how interactions should unfold, and how the basic units of interpersonal interaction (power, imposition, and possibly distance) differ or converge in different cultures to shape these expectations. As Meier (1995) has stated, "if 'politeness' be used as terminology, the preferable definition is to be found in appropriateness." Other scholars, such as Zimin (1981), Fraser and Nolen (1981), and Gu (1990) describe politeness in terms of doing what is socially acceptable. Some questions we would then ask are: Should greater politeness be shown to interactants of higher power and in instances of higher imposition? What is "higher power"? Is politeness shown using the same strategies in different cultures? Are the same strategies felt to have the same levels of politeness in the context of different cultures? This article aims to determine this set of questions.

\section{Research questions and methods}

\subsection{Research questions}

In an earlier study, the author has already shown that the main factors affecting the amount of politeness speakers feel is necessary are the listener's power, and the degree of imposition of a request (a finding which concurs with various earlier scholars as listed above). It is important to determine just what "power" is, as conceptual differences between cultures will almost certainly lead to differences in the degree of politeness used. Assuming that "power" is idealized similarly in two different cultures, the next step would be to determine how these "characteristics of power" translate into the real world, such as which people are perceived to have power. Lastly, in order to tie in these findings with a cognitive linguistic view of politeness, we must analyze whether similar politeness strategies are deemed to be appropriate in the same situations or towards the same interlocutors when used by speakers from different cultural backgrounds.

\subsection{Participants}

Participants of this study consisted of thirty-seven Chinese learners of English aged twelve to eighteen. The English proficiency level of these learners varied from intermediate to high intermediate as described by results from the IELTS English proficiency exam, and also from placement testing administered by the English First Language Institute, a world-wide language training institute originating from northern Europe. Additionally, 
fifteen native speakers of English were administered the same research questionnaire, so as to provide a basis for comparison with the results from the Chinese learner group.

\subsection{Data collection}

Data was collected by means of a two-part questionnaire. Part one, question one of this research questionnaire was meant to determine what factors make up power and social status for Chinese learners of English, and to compare the results with those gathered from native speakers of English. The question was presented in an open-ended format in hopes that responses would be as representative as possible of the subjects' personal beliefs, and not subjected to influence from frames of thought potentially not their own.

Question two of part one asked respondents to rank the power and social status of ten possible interactants. These interactants were based on an earlier study in the same vein conducted by Hill et al. (1986) in which there were twenty imagined interactants. The results of this question were compared to the results from native speakers of English once again, to determine if there would be similar ideas between the two groups. As it has been shown from earlier research that the relationship between politeness and social distance is a murky one at best, this question made it specifically clear that none of the possible interlocutors were ones with which the respondent was very familiar or close with.

Part two of this research questionnaire deals with the acceptability and appropriateness issues (of differing request strategies) identified by the scholars as listed above. In accordance with Locher and Watts (2005), this section attempts to tackle the question of politeness in terms of not only what is considered polite or impolite, but also what is seen as appropriate or acceptable while not necessarily marked as "polite". In addition to Locher and Watts' four partition frame of social interaction, the author has also added a fifth possibility, that of "acceptable but overly polite", as this might better describe a respondent's feelings about certain politeness strategies. As various scholars have identified before, what is considered acceptable in interaction may differ between cultures, thus leading to miscommunication and difficulties. This section of the questionnaire attempted to find and compare differences of acceptability and appropriateness between Chinese learners and native speakers of English.

The same nine possible politeness strategies were rated in two situations, that of when speaking to a person of higher social status or power, and in speaking to a person of equal social status or power. The politeness strategies used in this section were based on a study which tested similarities of politeness phenomenon across cultures conducted by Holtgraves and Yang (1990). One strategy represented the bald on record approach ("Go get the book"). Two other strategies show positive politeness by being optimistic ("You will get the book, right?") and a request in the form of asking for reasons ("Why don't you go get the book?"). Another request reflected the off record strategy (“The book is downstairs, isn't it?"). Lastly, five requests representing three negative politeness strategies were tested. Two stated the speaker's desire for action ("I want you to go get the book," "I would like you to go get the book."). Two other requests questioned the ability and possibility of the hearer taking action ("Could you go get the book?", "Would you go get the book?"). Finally, a request asked if there was imposition on the hearer ("Would it trouble you to go get the book?"). This is the order in which the strategies were presented, and corresponds to a low to high level of politeness as described by parameters set by Brown and Levinson (1978). The responses of the subjects were once again compared to those of native English speakers.

\section{Results and discussion}

\subsection{Factors which contribute to social status}

Question one of part one of the research questionnaire was constructed with the hope of determining which factors can contribute to (or potentially take away from) a person's social status, as is conceived from the point of view of Chinese learners of English. It was shown in earlier research that the perceived social status of a potential listener was a deciding factor when it came to the question of how much politeness is deemed appropriate to show when interacting with another. A wide range of responses were given as to which factors were felt to be relevant to this question. Money, knowledge, occupation, friends and acquaintances, family background, social behavior, and fame were some of the more common responses. Somewhat surprisingly to the author, age and education did not seem to weigh so heavily as originally hypothesized.

As has been mentioned before, the purpose of this research was to identify what the concepts of "power" and "social status" actually mean to speakers of Chinese and western culture, and to find similarities and differences between the two. Therefore, all research questions were administered to a group of western native English speakers as well, so as to gain information on which to compare and contrast. In responding to question one of 
part one, native English speakers rated money, ability/talent, education, knowledge, occupation, social behavior, and friends and acquaintances highly. While not absolutely mirroring images of each other, Chinese and native English speakers showed a great degree of overlap in their responses.

The greatest consistencies appeared for the factors of money, knowledge, and friends and acquaintances. Education, occupation, social behavior, and family background were also highly relevant for both respondent groups' perceptions of social power, but did not correlate amongst the two respondent groups to such a high degree. Race and gender, which were both prominent responses among native English speakers, were not given as responses by Chinese learners of English. It could be that here in Shanghai, where the research questionnaire was administered, the population is largely homogenous, and so the race factor was not considered by the Chinese learners of English. As for the gender issue, the Chinese government policy of advocating equality among the sexes has been in effect for decades, especially in urban areas, of which Shanghai belongs. It is possibly the success of this policy that has led respondents to overlook this factor as well. This is of course not to say that race and gender definitely do not factor into considerations of social power. Only further research into this issue could give an answer to this question. Additionally, the factor of physical appearance seems to have much more weight in western cultures than it does among Chinese learners of English.

\subsection{Hierarchical rankings of social status}

Question two of the research questionnaire was meant to discover if the basic conceptualizations of social hierarchy are similar between Chinese learners of English and native speakers of English. Respondents were asked to rank ten hypothetical individuals in accordance with their social status. The choice of "professor" rated the highest for the Chinese learners of English, and "waiter/waitress" was rated lowest. For native speakers of English, "professor" was also rated highest in social status, while "younger friend" was rated as lowest.

At first glance, it might seem that Chinese learners of English and native speakers of the language differ quite markedly in their perceptions of the makeup of the social hierarchy. However, if we remember that various researchers have found that the degree of social distance/closeness to an interlocutor can be confusing in terms of power, not only to Chinese learners, but also to native speakers themselves, we might reach a clearer picture. If we were to momentarily not consider the items of "older friend", "younger friend", and "classmate", we find marked similarities between the two groups of respondents. These three items all run the risk of having closeness with the interlocutor cloud a respondents' perception of power and social status. If we exclude these three items (shaded in table 2), we find an almost exact match among responses, with the only exception of "secretary" and "middle aged stranger" occupying switched positions between the two groups. While these particular order rankings might be considered a matter of fact among individuals of the same culture, we should see the significance here as we are comparing two supposedly greatly different groups of respondents.

\subsection{Perceptions of politeness and acceptability of individual request utterances}

Part two of the research questionnaire was designed with the purpose of determining perceptions of politeness and acceptability of different politeness strategies as described by Brown and Levinson. The results can once again be compared between Chinese learners and native speakers of English. Although it has been shown that these two groups have similar cognitive frames of what politeness is, with similar factors affecting their views of social power, we must also analyze how politeness is thought to be shown through verbal utterances. Only after this has been done can we further explore any discrepancies in ideals of politeness between cultures.

Question one of part two of the research questionnaire gave the hypothetical situation in which the speaker was making a request of the hearer, that of retrieving a book. The listener was stated to be one which was of higher social status and power than the speaker. Nine different request strategies were tested.

Question two of part two of the research questionnaire posed the same situation as in question one with the sole difference being that the listener was an individual of equal social status or power to the speaker.

After a comparison of responses by Chinese learners and native speakers of English, we can see some stark differences. Firstly, all request strategies were ranked lower in politeness and acceptability by native English speakers. That is to say that when presented with the same situation, native English speakers consistently felt that the degree of politeness needed was greater than what Chinese learners of English deemed was necessary. In the author's opinion, this should not be taken as a sign that one culture is more or less "polite" than the other. Alternatively, what is shown from these results is that the basic requirements in showing politeness are different in different cultures.

Another striking difference that is greatly apparent is the degree of variability of responses given by the two different groups. We can easily see that the native speakers of English group were fairly consistent in their responses, with one item accounting for the majority of responses in most utterances. Indeed, in eight of the utterances presented, there were only two responses chosen. Only two request utterances pushed the native 
speakers to give four differing responses. One utterance (the seventh of question two) "Could you go get the book?" was accounted for by only one response. Not a single utterance prompted all five responses.

In contrast to the native speakers of English, the Chinese learners were more varied in their feelings about politeness and acceptability. In four of the utterances presented, all five responses were felt to represent the feelings of at least one respondent. Twelve utterances saw four or more responses deemed to be representative of the respondents' feelings. No utterances were accounted for by only two or less responses. It should be remembered that this respondent group is still in the process of learning the English language, and so their perceptions of the language may yet be blurry, leading to the variability shown here.

Question three of part two of the research questionnaire presented respondents with a different situation, that in which the speaker is asking the listener to lend him/her one thousand dollars. This request is considerably more imposing than the previous one, and it was hoped that this would shed light on how degree of imposition affects perceptions of degree of politeness needed. The hypothetical listener in this question was an individual of higher social status or power.

Question four of part two of the research questionnaire gave respondents the same situation as question three, with the difference being that the speaker was speaking to a listener of equal social status or power.

The results of questions three and four closely followed what was found from the results of questions one and two. For the most part, native English speakers felt that the request utterances presented displayed a lower degree of politeness and acceptability than what was believed by the Chinese learners group. That is to say that the beliefs about the politeness hierarchy of request strategies was basically the same, but the Chinese learners group consistently found greater acceptability in each strategy. If we chose to see the results metaphorically as a set of stairs, the result would be two sets of the same stairs parallel to each other, with one set starting a few feet above the other.

Possibly the most interesting finding gained after analysis of all four questions in this research questionnaire comes from the third request strategy presented, (the positive politeness request strategy which asks for reasons) "why don't you..." The only exception to the twin stairs metaphor comes from this request strategy. Native English speakers found this request strategy to be rather unacceptable when speaking to listeners of higher social status or power in both imposition situations, and in keeping with the general findings, more so than the Chinese learner respondents. Inversely, when speaking to listeners of equal social status or power, the native English speakers greatly revised their opinions to generally acceptable views on this type of strategy. The Chinese learners group however, rated this request as still generally unfavorable, even more so than the native English speaker group. This is the only request strategy in which this "flipping" phenomenon occurs.

The author hypothesizes that this is due to a different understanding of the phrase "why don't you" between the two respondent groups. For native English speakers, this phrase would be seen as a gentle nudge in an effort to reach a desired result. For Chinese learners however, "why don't you" might be seen as a rather critical remark, similar to finding fault with another as a result of unfulfilled duties. As a result, this type of request strategy may be thought of as less polite in any situation whatsoever in the eyes of the Chinese learners than for the native speakers of English. This is only a hypothesis, and requires further research.

\subsection{Attitudes towards acceptability of differing request strategies}

We can gain additional insight if we compare the attitudes of acceptability of different kinds of request strategies as well.

The results show us that under almost all circumstances, the Chinese learner group felt a greater degree of acceptability for bald on requests than did the native speaker group. This pertained to listeners of higher social status in instances of both low and high imposition, and also towards listeners of equal social status in instances of high imposition. This propensity for not "dressing up" a request is no doubt a great factor when native English speakers label Chinese learners as "impolite". It is clear that what is felt as acceptable differs greatly between the two groups in so far as bald on requests are concerned.

When comparing the two groups in terms of their perceptions of positive request strategies, we find a very interesting contrast as well. The results show us that when speaking to listeners of higher social status or power (in both the low and high imposition situations), the Chinese learner group found much more acceptability in using positive request strategies than did the native speaker group. However, when speaking to listeners of equal social status or power, the native speaker group raised their acceptability ratings of this strategy greatly, even more so than did the Chinese learner group. It would seem that native English speakers are more aware of and considerate of "whom they are speaking to". Possibly this is due to the success of the Chinese government's decades long campaign for equality among the classes.

It has been said that positive politeness strategies represent a relatively low level of politeness (Holtgraves 2005). 
This would seem to lead to the conclusion that Chinese learners are relatively more polite towards their peers, whereas native English speakers are relatively more polite towards their superiors.

The degree of imposition factor had the expected results in line with findings by Brown and Gilman (1989), Holtgraves and Yang (1992), and Leichty and Applegate (1991) for both respondent groups, in that positive request strategies are used more towards listeners of equal social status or power, although the differences in acceptability are more pronounced for native speakers of English than for Chinese learners.

When analyzing the perceptions of the acceptability of off-record request strategies, we find that both Chinese learners and native English speakers find this strategy to be quite acceptable when the degree of imposition is low. However, when considering a situation of high request imposition, both groups rated this strategy as considerably lower in acceptability, especially when speaking to an individual of higher social status or power. This is possibly due to the fact that off-record request strategies are often seen as manipulative, and therefore impolite. Higher imposition requests have been shown to require higher politeness, and in accordance, both groups of respondents rated this type of strategy as less acceptable when in high imposition situations.

When analyzing the acceptability of negative politeness request strategies which involve the speaker in clearly stating their desires, we find that the results are very similar to the two groups' perceptions of positive request strategies. Chinese learners of English rated this strategy as more acceptable than native English speakers when the listener is an individual of higher social status or power. Again, the native English speaker group found this kind of strategy to be more acceptable when speaking to listeners of equal social status or power than did the Chinese learner group in the situation of low request imposition. The two groups rated the acceptability of this strategy roughly equally in the situation of equal social status or power, high request imposition. It should be noted that both groups favored "I would like you to" over the more direct "I want you to" as more acceptable in all request situations.

The results here seem to indicate again that Chinese learners of English are comparatively more polite towards their peers, while native English speakers are more polite towards superiors.

Negative politeness request strategies which inquire about the possibility of the hearer taking action is shown here to be the preferred strategy for both groups of respondents, with an acceptability rating which nears one hundred percent for Chinese learners of English, and total acceptability for native speakers of English. Request strategies which utilize modal verbs (could, would) are the most commonly taught strategy in language textbooks, and their apparent favor here is no surprise.

Lastly, when analyzing negative request strategies which inquire about imposition to the hearer, we can once again find differences between the two groups of respondents. While both groups also found this type of request strategy to be quite appropriate (roughly ninety percent among Chinese learners and a unanimous one hundred percent for native speakers), there were a small minority of Chinese learner respondents who felt this strategy to be unacceptable. The reason for this was that this strategy was felt to be "overly polite" to the point of unacceptability. Whether this perceived excess of politeness stems from the listener status, imposition degree, fear of seeming insincere, or some other reason remains to be identified and warrants further study.

All in all, the degree of imposition factor was proven correct, in that higher imposition was felt to warrant greater politeness. This result held true for both respondent groups.

\section{Conclusion}

The results of this study show us both similarities and differences when it comes to the topic of what "politeness" is in Chinese and western cultures. It was found that the factors which affect an individual's perception of social status are for the most part congruent in both cultures. We have also discovered that the hierarchical ranking of social status is quite similar between Chinese learners of English and native speakers. It can be said that within the cognitive frames of politeness of Chinese learners and English native speakers, which individuals warrant a higher degree of politeness usage is fairly agreed upon. The way in which to identify those individuals is also quite similar. The main difference between the two groups rests in the manner in which politeness is shown verbally. While the same methods and strategies (as described by Brown and Levinson) seem to be valid, and the hierarchy of politeness demonstrated by these strategies seems the same, a different requirement exists for how much politeness (or how high a strategy on the politeness ladder) is deemed necessary. Native English speakers apparently favor strategies slightly higher in the politeness hierarchy for all given situations and listeners, at least in the instance of making requests. The only exception found in this trend is in the situation of using positive politeness request strategies towards listeners of equal social status or power.

While the average layman would perhaps see this as an example of one culture being less "polite" than another, the cognitive view on politeness would show folly in this assumption. As Meier (1995) has stated, when researching politeness phenomenon, what should be the issue is not "an absolute measure of directness or of politeness, but rather the social interpretation of particular linguistic behavior within a particular speech 
community" (pg. 387). Politeness should be seen as a set of expectations about socially acceptable behavior under differing circumstances. To fulfill these expectations is to be "polite", and as different cultures have differing expectations, it is unfair and unreasonable to pass judgment when considering the norms of only one culture.

Having stated this important point, the author believes the next logical step would be to educate Chinese learners of English about this discrepancy in expectations. It is apparent from the results of this study that the lack of "politeness" in Chinese L2 learners as identified by native English speakers is due to what the author would like to call " $\mathrm{C} 1$ interference" (borrowing from the term L1 interference), or first culture interference. It is possible and quite probable that most Chinese learners of English below the advanced level are not aware of this difference in cultural expectations of politeness, as it is not a topic that is commonly addressed in English classes here in China (according to the author's limited experience). What to do with this knowledge would be of course up to the language learners themselves.

One of the largest limitations to this study lies in the number of participants that took part. The Chinese study group focused on school aged learners of English in Shanghai, which could be representative of a number of tier one cities, especially in coastal areas, but would not suffice to show the whole picture of English in China. That said, the author believes that this group of participants was a better choice than most for the topic under study, as it is these individuals who are the most likely to come in contact with the comparison group (native English speakers). With a larger number of this type of respondent, it might also have been possible to break down this demographic into smaller segments, differentiated by age. The author regrets not having the manpower and resources to pursue such an endeavor.

The latter participant group was even more lacking in numbers, but this is due to simple logistics. In the site where this study was conducted, native English speakers of a suitable age and occupation were not readily available. Obviously, most native English speakers in Shanghai are businessmen, company employees, or English teachers, none of which would have provided a suitable comparison group. Even the respondents deemed suitable (students) moved in and out of Shanghai sporadically, making it difficult to find consistent subjects for a study. Fortunately, it was found that this group of participants responded quite consistently on the topic of politeness, so it is believed that this lack of numbers does not affect the outcome of the study.

\section{References}

Arundale, R. B. (2006). Face as relational and interactional: A communication framework for research on face, facework, and politeness. Journal of Politeness Research. Language, Behaviour, Culture, 2, 193-216.

Axia, G. \& Baroni, M. R. (1985). Linguistic Politeness at Different Age Levels. Child Development, 56, 918-927.

Bou-Franch, P., \& Garcés-Conejos, P. (2003). Teaching linguistic politeness: A methodological proposal. IRAL International Review of Applied Linguistics in Language Teaching, 41, 1-22.

Carrel, P. L. \& Konneker, B. H. (1981). Polite-ness: Comparing Native and Nonnative Judgments. Language Learning, 31, 17-30.

Chen, R. (2001). Self-politeness: A proposal. Journal of Pragmatics, 33, 187-106.

Cicourel, A. V. (1981). The Role of Cognitive-Linguistic Concepts in Understanding Everyday Social Interactions. Annual Review of Sociology, 7, 87-106.

Escandell-Vidal, V. (1996). Towards a cognitive approach to politeness. Language Sciences, 18, 629-650.

Haugh, M. (2007). The discursive challenge to politeness research: An interactional alternative. Journal of Politeness Research. Language, Behaviour, Culture, 3, 295-317.

Hill, B., Ide, S., Ikuta, S., Kawasaki, A. \& Ogino, T. (1986). Universals of linguistic politeness: Quantitative evidence from Japanese and American English. Journal of Pragmatics, 10, 3347-371.

Holtgraves, T. (2005). Social Psychology, Cognitive Psychology, and Linguistic Politeness. Journal of Politeness Research. Language, Behaviour, Culture, 1, 73-93.

Holtgraves, T. \& Yang, J. (1990). Politeness as universal: Cross-cultural perceptions of request strategies and inferences based on their use. Journal of Personality and Social Psychology, 59, 719-729.

Janney, R. W. \& Arndt, H. (1993). Universality and relativity in cross-cultural politeness research: A historical perspective. Multilingua - Journal of Cross-Cultural and Interlanguage Communication, 12, 13-50.

Kasper, G. \& Rose, K. R. (1999). Pragmatics and SLA. Annual Review of Applied Linguistics, 19, 81-104.

Locher, M. A. \& Watts, R. J. (2008). Politeness Theory and Relational Work .Journal of Politeness Research. Language, Behaviour, Culture, 1, 9-33. 
Meier, A. J. (1995). Passages of politeness. Journal of Pragmatics, 24, 381-392.

Pan, Y. (1995). Power behind Linguistic Behavior Analysis of Politeness Phenomena in Chinese Official Settings. Journal of Language and Social Psychology, 14, 462-481.

Person, N. K., Kreuz, R. J., Zwaan, R. A. \& Graesser, A. C. (1995). Pragmatics and Pedagogy: Conversational Rules and Politeness Strategies May Inhibit Effective Tutoring. Cognition and Instruction, 13, 161 - 188.

Table 1. Factors which contribute to social power

\begin{tabular}{|l|l|l|}
\hline & $\begin{array}{l}\text { Chinese learners of English } \\
\text { response \% }\end{array}$ & $\begin{array}{l}\text { Native speakers of English } \\
\text { response \% }\end{array}$ \\
\hline Money & $70.2 \%$ & $66.7 \%$ \\
\hline Ability/talent & $21.6 \%$ & $40.0 \%$ \\
\hline Knowledge & $43.2 \%$ & $46.6 \%$ \\
\hline Education & $32.4 \%$ & $53.3 \%$ \\
\hline Occupation & $32.4 \%$ & $46.0 \%$ \\
\hline Age & $18.9 \%$ & $26.6 \%$ \\
\hline Self confidence & $2.7 \%$ & $13.3 \%$ \\
\hline Life experience & $8.1 \%$ & $\mathrm{n} / \mathrm{a}$ \\
\hline Friends and acquaintances & $40.5 \%$ & $40.0 \%$ \\
\hline Family background & $54.0 \%$ & $33.4 \%$ \\
\hline Fame & $24.3 \%$ & $13.3 \%$ \\
\hline Physical appearance & $8.1 \%$ & $40.0 \%$ \\
\hline Social behavior & $32.4 \%$ & $46.7 \%$ \\
\hline Race & $\mathrm{n} / \mathrm{a}$ & $40.0 \%$ \\
\hline Gender & $\mathrm{n} / \mathrm{a}$ & $26.6 \%$ \\
\hline
\end{tabular}

Table 2. Rankings of social status and average rank score

\begin{tabular}{|l|l|l|l|}
\hline Chinese learners of English & \multicolumn{2}{l|}{ Native speakers of English } \\
\hline Professor & 9.48 & Professor & 9.86 \\
\hline Police officer & 8.16 & Police officer & 8.60 \\
\hline Older friend & 6.64 & Middle aged stranger & 6.73 \\
\hline Secretary & 6.35 & Older friend & 6.33 \\
\hline Middle aged stranger & 5.29 & Secretary & 5.73 \\
\hline Classmate & 4.81 & Post office clerk & 4.86 \\
\hline Younger friend & 4.32 & Classmate & 4.20 \\
\hline Post office clerk & 4.05 & Store clerk & 3.66 \\
\hline Store clerk & 3.91 & Waiter/waitress & 3.06 \\
\hline Waiter/waitress & 3.54 & Younger friend & 1.93 \\
\hline
\end{tabular}

Table 3. Interactant of higher social status, low level of imposition

\begin{tabular}{|l|lr|lr|}
\hline Go get the book & $\begin{array}{l}\text { Chinese learners of } \\
\text { English response \% }\end{array}$ & $\begin{array}{l}\text { Native speakers of } \\
\text { English response \% }\end{array}$ \\
\hline Not acceptable and not polite & $54.0 \%$ & $73.3 \%$ & \\
\hline Acceptable but not polite & $40.5 \%$ & $26.6 \%$ & \\
\hline Acceptable and polite & $5.5 \%$ & $0 \%$ & \\
\hline Acceptable but overly polite & $0 \%$ & $0 \%$ & \\
\hline Not acceptable and overly polite & $0 \%$ & $0 \%$ & \\
\hline You will go get the book, right? & $\begin{array}{l}\text { Chinese learners of } \\
\text { English response \% }\end{array}$ & $\begin{array}{l}\text { Native speakers } \\
\text { English response \% }\end{array}$ \\
\hline Not acceptable and not polite & $2.7 \% \quad$ & $53.5 \%$ & \\
\hline
\end{tabular}




\begin{tabular}{|c|c|c|}
\hline Acceptable but not polite & $51.4 \%$ & $40.0 \%$ \\
\hline Acceptable and polite & $43.2 \%$ & $6.6 \%$ \\
\hline Acceptable but overly polite & $2.7 \%$ & $0 \%$ \\
\hline Not acceptable and overly polite & $0 \%$ & $0 \%$ \\
\hline Why don't you go get the book? & $\begin{array}{l}\text { Chinese learners of } \\
\text { English response \% }\end{array}$ & $\begin{array}{lrr}\text { Native } & \text { speakers } & \text { of } \\
\text { English response \% } & \\
\end{array}$ \\
\hline Not acceptable and not polite & $37.8 \%$ & $66.6 \%$ \\
\hline Acceptable but not polite & $29.7 \%$ & $26.6 \%$ \\
\hline Acceptable and polite & $27.0 \%$ & $6.6 \%$ \\
\hline Acceptable but overly polite & $5.5 \%$ & $0 \%$ \\
\hline Not acceptable and overly polite & $0 \%$ & $0 \%$ \\
\hline The book is downstairs, isn't it? & $\begin{array}{ll}\text { Chinese learners } & \text { of } \\
\text { English response \% } & \\
\end{array}$ & $\begin{array}{lrr}\text { Native } & \text { speakers } & \text { of } \\
\text { English response \% } & \\
\end{array}$ \\
\hline Not acceptable and not polite & $8.0 \%$ & $0 \%$ \\
\hline Acceptable but not polite & $18.9 \%$ & $33.3 \%$ \\
\hline Acceptable and polite & $45.9 \%$ & $60.0 \%$ \\
\hline Acceptable but overly polite & $18.9 \%$ & $6.6 \%$ \\
\hline Not acceptable and overly polite & $8.0 \%$ & $0 \%$ \\
\hline I want you to go get the book. & $\begin{array}{l}\text { Chinese learners of } \\
\text { English response \% }\end{array}$ & $\begin{array}{lrr}\text { Native } & \text { speakers } & \text { of } \\
\text { English response \% } & \\
\end{array}$ \\
\hline Not acceptable and not polite & $40.5 \%$ & $80.0 \%$ \\
\hline Acceptable but not polite & $35.0 \%$ & $6.6 \%$ \\
\hline Acceptable and polite & $18.9 \%$ & $13.3 \%$ \\
\hline Acceptable but overly polite & $2.7 \%$ & $0 \%$ \\
\hline Not acceptable and overly polite & $2.7 \%$ & $0 \%$ \\
\hline I would like you to go get the book. & $\begin{array}{l}\text { Chinese learners of } \\
\text { English response \% }\end{array}$ & $\begin{array}{lrr}\text { Native } & \text { speakers } & \text { of } \\
\text { English response \% } & \\
\end{array}$ \\
\hline Not acceptable and not polite & $8.0 \%$ & $20.0 \%$ \\
\hline Acceptable but not polite & $29.7 \%$ & $53.3 \%$ \\
\hline Acceptable and polite & $54.0 \%$ & $20.0 \%$ \\
\hline Acceptable but overly polite & $8.0 \%$ & $6.6 \%$ \\
\hline Not acceptable and overly polite & $0 \%$ & $0 \%$ \\
\hline Could you go get the book? & $\begin{array}{l}\text { Chinese learners of } \\
\text { English response \% }\end{array}$ & $\begin{array}{lrr}\text { Native } & \text { speakers } & \text { of } \\
\text { English response \% } & \\
\end{array}$ \\
\hline Not acceptable and not polite & $0 \%$ & $0 \%$ \\
\hline Acceptable but not polite & $5.5 \%$ & $33.3 \%$ \\
\hline Acceptable and polite & $86.4 \%$ & $66.6 \%$ \\
\hline Acceptable but overly polite & $8 \%$ & $0 \%$ \\
\hline Not acceptable and overly polite & $0 \%$ & $0 \%$ \\
\hline Would you go get the book? & $\begin{array}{l}\text { Chinese learners of } \\
\text { English response \% }\end{array}$ & $\begin{array}{lrr}\text { Native } & \text { speakers } & \text { of } \\
\text { English response \% } & \\
\end{array}$ \\
\hline Not acceptable and not polite & $2.7 \%$ & $0 \%$ \\
\hline Acceptable but not polite & $10.8 \%$ & $53.3 \%$ \\
\hline Acceptable and polite & $72.9 \%$ & $46.6 \%$ \\
\hline Acceptable but overly polite & $10.8 \%$ & $0 \%$ \\
\hline Not acceptable and overly polite & $2.7 \%$ & $0 \%$ \\
\hline Would it trouble you to go get the book? & $\begin{array}{l}\text { Chinese learners of } \\
\text { English response \% }\end{array}$ & $\begin{array}{lrr}\text { Native } & \text { speakers } & \text { of } \\
\text { English response \% } & \\
\end{array}$ \\
\hline Not acceptable and not polite & $0 \%$ & $0 \%$ \\
\hline Acceptable but not polite & $0 \%$ & $0 \%$ \\
\hline Acceptable and polite & $37.8 \%$ & $73.3 \%$ \\
\hline Acceptable but overly polite & $54.0 \%$ & $26.6 \%$ \\
\hline Not acceptable and overly polite & $8.0 \%$ & $0 \%$ \\
\hline
\end{tabular}


Table 4. Interactant of equal social status, low level of imposition

\begin{tabular}{|c|c|c|}
\hline Go get the book. & $\begin{array}{l}\text { Chinese learners } \\
\text { English response \% }\end{array}$ & $\begin{array}{lrr}\text { Native } \quad \text { speakers } & \text { of } \\
\text { English response \% } & \\
\end{array}$ \\
\hline Not acceptable and not polite & $43.2 \%$ & $26.6 \%$ \\
\hline Acceptable but not polite & $45.9 \%$ & $60.0 \%$ \\
\hline Acceptable and polite & $10.8 \%$ & $13.3 \%$ \\
\hline Acceptable but overly polite & $0 \%$ & $0 \%$ \\
\hline Not acceptable and overly polite & $0 \%$ & $0 \%$ \\
\hline You will go get the book, right? & $\begin{array}{l}\text { Chinese learners } \\
\text { English response \% }\end{array}$ & $\begin{array}{lrr}\text { Native } \quad \text { speakers } & \text { of } \\
\text { English response } \% & \\
\end{array}$ \\
\hline Not acceptable and not polite & $10.8 \%$ & $0 \%$ \\
\hline Acceptable but not polite & $24.3 \%$ & $20.0 \%$ \\
\hline Acceptable and polite & $56.7 \%$ & $80.0 \%$ \\
\hline Acceptable but overly polite & $8.0 \%$ & $0 \%$ \\
\hline Not acceptable and overly polite & $0 \%$ & $0 \%$ \\
\hline Why don't you go get the book? & $\begin{array}{l}\text { Chinese learners } \\
\text { English response \% }\end{array}$ & $\begin{array}{lrr}\text { Native speakers } & \text { of } \\
\text { English response \% } & \\
\end{array}$ \\
\hline Not acceptable and not polite & $24.3 \%$ & $6.6 \%$ \\
\hline Acceptable but not polite & $27.0 \%$ & $60.0 \%$ \\
\hline Acceptable and polite & $35.0 \%$ & $26.6 \%$ \\
\hline Acceptable but overly polite & $5.5 \%$ & $6.6 \%$ \\
\hline Not acceptable and overly polite & $0 \%$ & $0 \%$ \\
\hline The book is downstairs, isn't it? & $\begin{array}{l}\text { Chinese learners } \\
\text { English response \% }\end{array}$ & $\begin{array}{lrr}\text { Native } \quad \text { speakers } & \text { of } \\
\text { English response } \% & \\
\end{array}$ \\
\hline Not acceptable and not polite & $2.7 \%$ & $0 \%$ \\
\hline Acceptable but not polite & $21.6 \%$ & $6.6 \%$ \\
\hline Acceptable and polite & $59.5 \%$ & $86.6 \%$ \\
\hline Acceptable but overly polite & $10.8 \%$ & $6.6 \%$ \\
\hline Not acceptable and overly polite & $5.5 \%$ & $0 \%$ \\
\hline I want you to go get the book. & $\begin{array}{lll}\text { Chinese } \quad \text { learners } & \text { of } \\
\text { English response \% } & \\
\end{array}$ & $\begin{array}{lrr}\text { Native } \quad \text { speakers } & \text { of } \\
\text { English response \% } & \\
\end{array}$ \\
\hline Not acceptable and not polite & $37.8 \%$ & $26.6 \%$ \\
\hline Acceptable but not polite & $43.2 \%$ & $40.0 \%$ \\
\hline Acceptable and polite & $16.2 \%$ & $33.3 \%$ \\
\hline Acceptable but overly polite & $2.7 \%$ & $0 \%$ \\
\hline Not acceptable and overly polite & $0 \%$ & $0 \%$ \\
\hline I would like you to go get the book. & $\begin{array}{l}\text { Chinese learners } \\
\text { English response \% }\end{array}$ & $\begin{array}{lrr}\text { Native } \quad \text { speakers } & \text { of } \\
\text { English response \% } & \\
\end{array}$ \\
\hline Not acceptable and not polite & $2.7 \%$ & $0 \%$ \\
\hline Acceptable but not polite & $37.8 \%$ & $13.3 \%$ \\
\hline Acceptable and polite & $40.5 \%$ & $80.0 \%$ \\
\hline Acceptable but overly polite & $18.9 \%$ & $6.6 \%$ \\
\hline Not acceptable and overly polite & $0 \%$ & $0 \%$ \\
\hline Could you go get the book? & $\begin{array}{ll}\text { Chinese learners } & \text { of } \\
\text { English response \% } & \\
\end{array}$ & $\begin{array}{lrr}\text { Native } \quad \text { speakers } & \text { of } \\
\text { English response \% } & \\
\end{array}$ \\
\hline Not acceptable and not polite & $0 \%$ & $0 \%$ \\
\hline Acceptable but not polite & $5.5 \%$ & $0 \%$ \\
\hline Acceptable and polite & $67.5 \%$ & $100.0 \%$ \\
\hline Acceptable but overly polite & $27.0 \%$ & $0 \%$ \\
\hline Not acceptable and overly polite & $0 \%$ & $0 \%$ \\
\hline Would you go get the book? & $\begin{array}{ll}\text { Chinese learners } & \text { of } \\
\text { English response \% } & \\
\end{array}$ & $\begin{array}{lrr}\text { Native speakers } & \text { of } \\
\text { English response \% } & \\
\end{array}$ \\
\hline Not acceptable and not polite & $0 \%$ & $0 \%$ \\
\hline Acceptable but not polite & $2.7 \%$ & $0 \%$ \\
\hline
\end{tabular}




\begin{tabular}{|l|l|l|}
\hline Acceptable and polite & $70.2 \%$ & $93.3 \%$ \\
\hline Acceptable but overly polite & $24.3 \%$ & $6.6 \%$ \\
\hline Not acceptable and overly polite & $2.7 \%$ & $0 \%$ \\
\hline Would it trouble you to go get the book? & $\begin{array}{l}\text { Chinese learners of } \\
\text { English response \% }\end{array}$ & $\begin{array}{l}\text { Native speakers of } \\
\text { English response \% }\end{array}$ \\
\hline Not acceptable and not polite & $0 \%$ & $0 \%$ \\
\hline Acceptable but not polite & $0 \%$ & $0 \%$ \\
\hline Acceptable and polite & $21.6 \%$ & $26.6 \%$ \\
\hline Acceptable but overly polite & $67.5 \%$ & $73.3 \%$ \\
\hline Not acceptable and overly polite & $10.8 \%$ & $0 \%$ \\
\hline
\end{tabular}

Table 5. Interactant of higher social status, high level of imposition

\begin{tabular}{|c|c|c|}
\hline Lend me a thousand dollars. & $\begin{array}{l}\text { Chinese learners } \\
\text { English response \% }\end{array}$ & $\begin{array}{lrr}\text { Native } & \text { speakers } & \text { of } \\
\text { English response } \% & \\
\end{array}$ \\
\hline Not acceptable and not polite & $81.0 \%$ & $86.6 \%$ \\
\hline Acceptable but not polite & $16.2 \%$ & $13.3 \%$ \\
\hline Acceptable and polite & $2.7 \%$ & $0 \%$ \\
\hline Acceptable but overly polite & $0 \%$ & $0 \%$ \\
\hline Not acceptable and overly polite & $0 \%$ & $0 \%$ \\
\hline $\begin{array}{l}\text { You will lend me a thousand dollars, } \\
\text { right? }\end{array}$ & $\begin{array}{l}\text { Chinese learners } \\
\text { English response \% }\end{array}$ & $\begin{array}{lrr}\text { Native } & \text { speakers } & \text { of } \\
\text { English response \% } & \\
\end{array}$ \\
\hline Not acceptable and not polite & $32.4 \%$ & $73.3 \%$ \\
\hline Acceptable but not polite & $45.9 \%$ & $20.0 \%$ \\
\hline Acceptable and polite & $16.2 \%$ & $6.6 \%$ \\
\hline Acceptable but overly polite & $2.7 \%$ & $0 \%$ \\
\hline Not acceptable and overly polite & $2.7 \%$ & $0 \%$ \\
\hline $\begin{array}{l}\text { Why don't you lend me a thousand } \\
\text { dollars? }\end{array}$ & $\begin{array}{l}\text { Chinese learners } \\
\text { English response \% }\end{array}$ & $\begin{array}{lrr}\text { Native } & \text { speakers } & \text { of } \\
\text { English response } \% & \\
\end{array}$ \\
\hline Not acceptable and not polite & $67.5 \%$ & $66.6 \%$ \\
\hline Acceptable but not polite & $18.9 \%$ & $20.0 \%$ \\
\hline Acceptable and polite & $5.5 \%$ & $13.3 \%$ \\
\hline Acceptable but overly polite & $5.5 \%$ & $0 \%$ \\
\hline Not acceptable and overly polite & $2.7 \%$ & $0 \%$ \\
\hline You have a thousand dollars, right? & $\begin{array}{l}\text { Chinese learners } \\
\text { English response \% }\end{array}$ & $\begin{array}{lrr}\text { Native } \quad \text { speakers } & \text { of } \\
\text { English response \% } & \\
\end{array}$ \\
\hline Not acceptable and not polite & $55.5 \%$ & $73.3 \%$ \\
\hline Acceptable but not polite & $24.3 \%$ & $13.3 \%$ \\
\hline Acceptable and polite & $8.0 \%$ & $13.3 \%$ \\
\hline Acceptable but overly polite & $5.5 \%$ & $0 \%$ \\
\hline Not acceptable and overly polite & $2.7 \%$ & $0 \%$ \\
\hline I want you to lend me a thousand dollars. & $\begin{array}{l}\text { Chinese learners } \\
\text { English response \% }\end{array}$ & $\begin{array}{lrr}\text { Native } & \text { speakers } & \text { of } \\
\text { English response \% } & \\
\end{array}$ \\
\hline Not acceptable and not polite & $37.8 \%$ & $53.3 \%$ \\
\hline Acceptable but not polite & $37.8 \%$ & $33.3 \%$ \\
\hline Acceptable and polite & $21.6 \%$ & $13.3 \%$ \\
\hline Acceptable but overly polite & $2.7 \%$ & $0 \%$ \\
\hline Not acceptable and overly polite & $0 \%$ & $0 \%$ \\
\hline $\begin{array}{l}\text { I would like you to lend me a thousand } \\
\text { dollars. }\end{array}$ & $\begin{array}{l}\text { Chinese learners } \\
\text { English response \% }\end{array}$ & $\begin{array}{lrr}\text { Native } & \text { speakers } & \text { of } \\
\text { English response } \% & \\
\end{array}$ \\
\hline Not acceptable and not polite & $8.0 \%$ & $6.6 \%$ \\
\hline Acceptable but not polite & $45.9 \%$ & $53.3 \%$ \\
\hline Acceptable and polite & $43.2 \%$ & $40.0 \%$ \\
\hline Acceptable but overly polite & $0 \%$ & $0 \%$ \\
\hline Not acceptable and overly polite & $2.7 \%$ & $0 \%$ \\
\hline
\end{tabular}




\begin{tabular}{|c|c|c|}
\hline Could you lend me a thousand dollars? & $\begin{array}{l}\text { Chinese learners } \\
\text { English response \% }\end{array}$ & $\begin{array}{lr}\text { Native } \quad \text { speakers } & \text { of } \\
\text { English response \% } & \end{array}$ \\
\hline Not acceptable and not polite & $0 \%$ & $0 \%$ \\
\hline Acceptable but not polite & $13.5 \%$ & $33.3 \%$ \\
\hline Acceptable and polite & $78.3 \%$ & $66.6 \%$ \\
\hline Acceptable but overly polite & $8.0 \%$ & $0 \%$ \\
\hline Not acceptable and overly polite & $0 \%$ & $0 \%$ \\
\hline Would you lend me a thousand dollars? & $\begin{array}{l}\text { Chinese learners } \\
\text { English response \% }\end{array}$ & $\begin{array}{lrr}\text { Native } & \text { speakers } & \text { of } \\
\text { English response \% } & \end{array}$ \\
\hline Not acceptable and not polite & $0 \%$ & $0 \%$ \\
\hline Acceptable but not polite & $13.5 \%$ & $40.0 \%$ \\
\hline Acceptable and polite & $75.6 \%$ & $60.0 \%$ \\
\hline Acceptable but overly polite & $10.8 \%$ & $0 \%$ \\
\hline Not acceptable and overly polite & $0 \%$ & $0 \%$ \\
\hline $\begin{array}{l}\text { Would it trouble you to lend me a } \\
\text { thousand dollars? }\end{array}$ & $\begin{array}{l}\text { Chinese learners } \\
\text { English response \% }\end{array}$ & $\begin{array}{lrr}\text { Native } & \text { speakers } & \text { of } \\
\text { English response \% } & \end{array}$ \\
\hline$\overline{\text { Not acceptable and not polite }}$ & $0 \%$ & $0 \%$ \\
\hline Acceptable but not polite & $2.7 \%$ & $0 \%$ \\
\hline Acceptable and polite & $64.8 \%$ & $86.6 \%$ \\
\hline Acceptable but overly polite & $21.6 \%$ & $13.3 \%$ \\
\hline Not acceptable and overly polite & $10.8 \%$ & $0 \%$ \\
\hline
\end{tabular}

Table 6. Interactant of equal social status, high level of imposition

\begin{tabular}{|c|c|c|}
\hline Lend me a thousand dollars. & $\begin{array}{l}\text { Chinese learners } \\
\text { English response \% }\end{array}$ & $\begin{array}{lr}\text { Native } \quad \text { speakers } & \text { of } \\
\text { English response \% } & \end{array}$ \\
\hline Not acceptable and not polite & $45.9 \%$ & $53.3 \%$ \\
\hline Acceptable but not polite & $45.9 \%$ & $46.6 \%$ \\
\hline Acceptable and polite & $8.0 \%$ & $0 \%$ \\
\hline Acceptable but overly polite & $0 \%$ & $0 \%$ \\
\hline Not acceptable and overly polite & $0 \%$ & $0 \%$ \\
\hline $\begin{array}{l}\text { You will lend me a thousand dollars, } \\
\text { right? }\end{array}$ & $\begin{array}{l}\text { Chinese learners } \\
\text { English response \% }\end{array}$ & $\begin{array}{lrr}\text { Native } & \text { speakers } & \text { of } \\
\text { English response \% } & \\
\end{array}$ \\
\hline Not acceptable and not polite & $37.8 \%$ & $40.0 \%$ \\
\hline Acceptable but not polite & $32.4 \%$ & $40.0 \%$ \\
\hline Acceptable and polite & $27.0 \%$ & $20.0 \%$ \\
\hline Acceptable but overly polite & $2.7 \%$ & $0 \%$ \\
\hline Not acceptable and overly polite & $0 \%$ & $0 \%$ \\
\hline $\begin{array}{l}\text { Why don't you lend me a thousand } \\
\text { dollars? }\end{array}$ & $\begin{array}{l}\text { Chinese learners } \\
\text { English response \% }\end{array}$ & $\begin{array}{lr}\text { Native speakers } & \text { of } \\
\text { English response \% } & \end{array}$ \\
\hline Not acceptable and not polite & $43.2 \%$ & $26.6 \%$ \\
\hline Acceptable but not polite & $37.8 \%$ & $53.3 \%$ \\
\hline Acceptable and polite & $13.5 \%$ & $20.0 \%$ \\
\hline Acceptable but overly polite & $5.4 \%$ & $0 \%$ \\
\hline Not acceptable and overly polite & $0 \%$ & $0 \%$ \\
\hline You have a thousand dollars, right? & $\begin{array}{l}\text { Chinese learners } \\
\text { English response \% }\end{array}$ & $\begin{array}{lrr}\text { Native } & \text { speakers } & \text { of } \\
\text { English response \% } & \end{array}$ \\
\hline Not acceptable and not polite & $32.4 \%$ & $33.3 \%$ \\
\hline Acceptable but not polite & $45.9 \%$ & $46.6 \%$ \\
\hline Acceptable and polite & $10.8 \%$ & $20.0 \%$ \\
\hline Acceptable but overly polite & $8.0 \%$ & $0 \%$ \\
\hline Not acceptable and overly polite & $2.7 \%$ & $0 \%$ \\
\hline I want you to lend me a thousand dollars. & $\begin{array}{l}\text { Chinese learners } \\
\text { English response \% }\end{array}$ & $\begin{array}{lr}\text { Native } \quad \text { speakers } & \text { of } \\
\text { English response \% } & \end{array}$ \\
\hline Not acceptable and not polite & $37.8 \%$ & $40.0 \%$ \\
\hline
\end{tabular}




\begin{tabular}{|c|c|c|}
\hline Acceptable but not polite & $48.6 \%$ & $40.0 \%$ \\
\hline Acceptable and polite & $10.8 \%$ & $20.0 \%$ \\
\hline Acceptable but overly polite & $2.7 \%$ & $0 \%$ \\
\hline Not acceptable and overly polite & $0 \%$ & $0 \%$ \\
\hline $\begin{array}{l}\text { I would like you to lend me a thousand } \\
\text { dollars. }\end{array}$ & $\begin{array}{ll}\text { Chinese } \quad \begin{array}{l}\text { learners } \\
\text { English response \% }\end{array} \\
\end{array}$ & $\begin{array}{lrr}\text { Native } & \text { speakers } & \text { of } \\
\text { English response \% } & \\
\end{array}$ \\
\hline Not acceptable and not polite & $10.8 \%$ & $0 \%$ \\
\hline Acceptable but not polite & $37.8 \%$ & $13.3 \%$ \\
\hline Acceptable and polite & $43.2 \%$ & $73.3 \%$ \\
\hline Acceptable but overly polite & $5.5 \%$ & $13.3 \%$ \\
\hline Not acceptable and overly polite & $2.7 \%$ & $0 \%$ \\
\hline Could you lend me a thousand dollars? & $\begin{array}{lll}\text { Chinese } & \text { learners } \\
\text { English response \% } & \text { of } \\
\end{array}$ & $\begin{array}{lrr}\text { Native } & \text { speakers } & \text { of } \\
\text { English response \% } & \\
\end{array}$ \\
\hline Not acceptable and not polite & $0 \%$ & $0 \%$ \\
\hline Acceptable but not polite & $5.5 \%$ & $0 \%$ \\
\hline Acceptable and polite & $78.3 \%$ & $100.0 \%$ \\
\hline Acceptable but overly polite & $13.5 \%$ & $0 \%$ \\
\hline Not acceptable and overly polite & $2.7 \%$ & $0 \%$ \\
\hline Would you lend me a thousand dollars? & $\begin{array}{l}\text { Chinese learners of } \\
\text { English response \% }\end{array}$ & $\begin{array}{lrr}\text { Native } & \text { speakers } & \text { of } \\
\text { English response \% } & \\
\end{array}$ \\
\hline Not acceptable and not polite & $0 \%$ & $0 \%$ \\
\hline Acceptable but not polite & $2.7 \%$ & $6.6 \%$ \\
\hline Acceptable and polite & $81.0 \%$ & $93.3 \%$ \\
\hline Acceptable but overly polite & $13.5 \%$ & $0 \%$ \\
\hline Not acceptable and overly polite & $2.7 \%$ & $0 \%$ \\
\hline $\begin{array}{l}\text { Would it trouble you to lend me a } \\
\text { thousand dollars? }\end{array}$ & $\begin{array}{l}\text { Chinese learners } \\
\text { English response \% }\end{array}$ & $\begin{array}{lrr}\text { Native } & \text { speakers } & \text { of } \\
\text { English response } \% & \\
\end{array}$ \\
\hline Not acceptable and not polite & $0 \%$ & $0 \%$ \\
\hline Acceptable but not polite & $0 \%$ & $0 \%$ \\
\hline Acceptable and polite & $56.7 \%$ & $66.6 \%$ \\
\hline Acceptable but overly polite & $32.4 \%$ & $33.3 \%$ \\
\hline Not acceptable and overly polite & $10.8 \%$ & $0 \%$ \\
\hline
\end{tabular}

Table 7.1. Acceptability of bald on request strategy, Chinese learners

\begin{tabular}{|l|l|l|}
\hline & $\begin{array}{l}\text { Listener of higher social status or } \\
\text { power }\end{array}$ & $\begin{array}{l}\text { Listener of equal social status or } \\
\text { power }\end{array}$ \\
\hline Lower request imposition & $46.0 \%$ & $56.7 \%$ \\
\hline Higher request imposition & $18.9 \%$ & $53.9 \%$ \\
\hline
\end{tabular}

Table 7.2. Acceptability of bald on request strategy, native English speakers

\begin{tabular}{|l|l|l|}
\hline & $\begin{array}{l}\text { Listener of higher social status or } \\
\text { power }\end{array}$ & $\begin{array}{l}\text { Listener of equal social status or } \\
\text { power }\end{array}$ \\
\hline Lower request imposition & $26.6 \%$ & $73.3 \%$ \\
\hline Higher request imposition & $13.3 \%$ & $46.6 \%$ \\
\hline
\end{tabular}

Table 8.1. Acceptability of positive politeness strategy, Chinese learners

\begin{tabular}{|l|l|l|}
\hline & $\begin{array}{l}\text { Listener of higher social status or } \\
\text { power }\end{array}$ & $\begin{array}{l}\text { Listener of equal social status or } \\
\text { power }\end{array}$ \\
\hline Lower request imposition & $79.7 \%$ & $78.2 \%$ \\
\hline Higher request imposition & $47.3 \%$ & $59.4 \%$ \\
\hline
\end{tabular}


Table 8.2. Acceptability of positive politeness strategy, native English speakers

\begin{tabular}{|l|l|l|}
\hline & $\begin{array}{l}\text { Listener of higher social status or } \\
\text { power }\end{array}$ & $\begin{array}{l}\text { Listener of equal social status or } \\
\text { power }\end{array}$ \\
\hline Lower request imposition & $39.9 \%$ & $93.3 \%$ \\
\hline Higher request imposition & $29.9 \%$ & $66 . .6 \%$ \\
\hline
\end{tabular}

Table 9.1. Acceptability of off-record request strategy, Chinese learners

\begin{tabular}{|l|l|l|}
\hline & $\begin{array}{l}\text { Listener of higher social status or } \\
\text { power }\end{array}$ & $\begin{array}{l}\text { Listener of equal social status or } \\
\text { power }\end{array}$ \\
\hline Lower request imposition & $83.7 \%$ & $91.9 \%$ \\
\hline Higher request imposition & $37.8 \%$ & $64.7 \%$ \\
\hline
\end{tabular}

Table 9.2. Acceptability of off-record request strategy, native English speakers

\begin{tabular}{|l|l|l|}
\hline & $\begin{array}{l}\text { Listener of higher social status or } \\
\text { power }\end{array}$ & $\begin{array}{l}\text { Listener of equal social status or } \\
\text { power }\end{array}$ \\
\hline Lower request imposition & $100.0 \%$ & $100.0 \%$ \\
\hline Higher request imposition & $26.6 \%$ & $66.6 \%$ \\
\hline
\end{tabular}

Table 10.1. Acceptability of negative request strategy (stating desire), Chinese learners

\begin{tabular}{|l|l|l|}
\hline & $\begin{array}{l}\text { Listener of higher social status or } \\
\text { power }\end{array}$ & $\begin{array}{l}\text { Listener of equal social status or } \\
\text { power }\end{array}$ \\
\hline Lower request imposition & $74.1 \%$ & $79.6 \%$ \\
\hline Higher request imposition & $75.6 \%$ & $74.3 \%$ \\
\hline
\end{tabular}

Table 10.2. Acceptability of negative request strategy (stating desire), native English speakers

\begin{tabular}{|l|l|l|}
\hline & $\begin{array}{l}\text { Listener of higher social status or } \\
\text { power }\end{array}$ & $\begin{array}{l}\text { Listener of equal social status or } \\
\text { power }\end{array}$ \\
\hline Lower request imposition & $49.9 \%$ & $86.6 \%$ \\
\hline Higher request imposition & $69.9 \%$ & $73.3 \%$ \\
\hline
\end{tabular}

Table 11.1. Acceptability of negative request strategy (question possibility), Chinese learners

\begin{tabular}{|l|l|l|}
\hline & $\begin{array}{l}\text { Listener of higher social status or } \\
\text { power }\end{array}$ & $\begin{array}{l}\text { Listener of equal social status or } \\
\text { power }\end{array}$ \\
\hline Lower request imposition & $97.2 \%$ & $98.6 \%$ \\
\hline Higher request imposition & $100.0 \%$ & $97.5 \%$ \\
\hline
\end{tabular}

Table 11.2. Acceptability of negative request strategy (question possibility), native English speakers

\begin{tabular}{|l|l|l|}
\hline & $\begin{array}{l}\text { Listener of higher social status or } \\
\text { power }\end{array}$ & $\begin{array}{l}\text { Listener of equal social status or } \\
\text { power }\end{array}$ \\
\hline Lower request imposition & $100.0 \%$ & $100.0 \%$ \\
\hline Higher request imposition & $100.0 \%$ & $100.0 \%$ \\
\hline
\end{tabular}

Table 12.1. Acceptability of negative request strategy (inquiring about imposition), Chinese learners

\begin{tabular}{|l|l|l|}
\hline & $\begin{array}{l}\text { Listener of higher social status or } \\
\text { power }\end{array}$ & $\begin{array}{l}\text { Listener of equal social status or } \\
\text { power }\end{array}$ \\
\hline Lower request imposition & $91.8 \%$ & $89.1 \%$ \\
\hline Higher request imposition & $89.1 \%$ & $89.1 \%$ \\
\hline
\end{tabular}

Table 12.2. Acceptability of negative request strategy (inquiring about imposition), native English speakers

\begin{tabular}{|l|l|l|}
\hline & $\begin{array}{l}\text { Listener of higher social status or } \\
\text { power }\end{array}$ & $\begin{array}{l}\text { Listener of equal social status or } \\
\text { power }\end{array}$ \\
\hline Lower request imposition & $100.0 \%$ & $100.0 \%$ \\
\hline Higher request imposition & $100.0 \%$ & $100.0 \%$ \\
\hline
\end{tabular}

